\title{
Cytotoxicity and Antiproliferative Activity Assay of Clove Mistletoe (Dendrophthoe pentandra (L.) Miq.) Leaves Extracts
}

\author{
Vida Elsyana, ${ }^{1}$ Maria Bintang, ${ }^{1}$ and Bambang Pontjo Priosoeryanto ${ }^{2}$ \\ ${ }^{1}$ Department of Biochemistry, Faculty of Mathematics and Natural Sciences, Bogor Agricultural University, Bogor 16680, Indonesia \\ ${ }^{2}$ Department of Veterinary Clinic, Reproduction and Pathology, Faculty of Veterinary Medicine, Bogor Agricultural University, \\ Bogor 16680, Indonesia
}

Correspondence should be addressed to Maria Bintang; maria_bintang@yahoo.com

Received 24 November 2015; Revised 21 February 2016; Accepted 8 March 2016

Academic Editor: Antonio Ferrer-Montiel

Copyright (C) 2016 Vida Elsyana et al. This is an open access article distributed under the Creative Commons Attribution License, which permits unrestricted use, distribution, and reproduction in any medium, provided the original work is properly cited.

\begin{abstract}
Clove mistletoe (Dendrophthoe pentandra (L.) Miq.) is a semiparasitic plant that belongs to Loranthaceae family. Clove mistletoe was traditionally used for cancer treatment in Indonesia. In the present study, we examined cytotoxicity of clove mistletoe leaves extracts against brine shrimps and conducted their antiproliferative activity on K562 (human chronic myelogenous leukemia) and MCM-B2 (canine benign mixed mammary) cancer cell lines in vitro. The tested samples were water extract, ethanol extract, ethanol fraction, ethyl acetate fraction, and n-hexane fraction. Cytotoxicity was screened using Brine Shrimp Lethality Test (BSLT). Antiproliferative activity was conducted using Trypan Blue Dye Method and cells were counted using haemocytometer. The results showed that $\mathrm{n}$ hexane fraction exhibited significant cytotoxicity with $\mathrm{LC}_{50}$ value of $55.31 \mu \mathrm{g} / \mathrm{mL}$. The $\mathrm{n}$-hexane fraction was then considered for further examination. The n-hexane fraction of clove mistletoe could inhibit growth of K562 and MCM-B2 cancer cell lines in vitro. The inhibition activity of clove mistletoe $\mathrm{n}$-hexane fraction at concentration of $125 \mu \mathrm{g} / \mathrm{mL}$ on $\mathrm{K} 562$ cancer cell lines was $38.69 \%$, while on MCM-B2 it was 41.5\%. Therefore, it was suggested that clove mistletoe had potential natural anticancer activity.
\end{abstract}

\section{Introduction}

Dendrophthoe pentandra (L.) Miq. is known as mistletoe and belongs to the Loranthaceae family. In Indonesia, mistletoe is commonly known as "benalu" and it is named depending on its host plant, for example, "benalu teh" (mistletoe that grew on tea as host plant). Since D. pentandra is a semiparasitic plant, it reduces productivity of horticultural plants. Nevertheless, $D$. pentandra was used traditionally for cough, diabetes, hypertension, cancer, diuretic, smallpox, ulcer, skin infection, and after child-birth treatments in Indonesia and other countries [1]. D. pentandra live on host plants to obtain food, water, and support by connecting to the host xylem via haustorium [2]. Thus, bioactivities of $D$. pentandra could also depend on its host plants where it grew [3].

Decoction of $D$. pentandra was used as complementary/alternative medicine for cancer treatment by Indonesian and Malay communities [4]. D. pentandra that grew on various host plants were reported to have cytotoxic and anticancer activities. Daniel et al. [5] reported that ethyl acetate fraction of $D$. pentandra on soursop as host plant had cytotoxic activity against brine shrimp. Gamal and Septananda [6] revealed that $D$. pentandra growing on cottonwood decreased mutant $\mathrm{p} 53$ protein expression in HeLa cells in vitro. Tristanti et al. [7] studied the hepatoprotective effect of ethanol leaves extract of $D$. pentandra growing on langsat on wistar albino rats induced by carbon tetrachloride and suggested that this plant had hepatoprotective activity. D. pentandra growing on mango showed an ability to recover goblet cells and to repair abnormalities in colon tissue (dysplasia) [8]. D. pentandra extract induced proliferation of mice splenocyte and thymocytes in a time- and dose-dependent manner [9].

There were several reports on bioactivities and phytochemical of mistletoe that grows on clove (clove mistletoe). Clove mistletoe leaves were found to have free radical scavenging activities [10]. Phytochemical screening of clove mistletoe leaves contained flavonoids, saponins, tannins, and triterpenoids compounds [11]. Flavonoid compounds are known to have an important role in cancer prevention [12]. 
However, cytotoxic and anticancer activities of clove mistletoe are still rare and some reports would be useful to provide information on plants that contain anticancer compounds.

In the present study, we examined cytotoxic activity of clove mistletoe leaves extracts against brine shrimps and their antiproliferative activity on K562 (human chronic myelogenous leukemia) and MCM-B2 (canine benign mixed mammary) cancer cell lines in vitro. The K562 and MCMB2 cells are frequently used as model in the study of in vitro antiproliferative activity [13-18]. Clove mistletoe leaves extract would be expected to have cytotoxic activity against brine shrimps and inhibited proliferation of cancer cells.

\section{Material and Methods}

2.1. Plants Materials. The fresh leaves of Dendrophthoe pentandra (L.) Miq. from clove as host plant were collected from Lampung, Indonesia, in January, 2015. The identity of sample was authenticated from Herbarium Bogoriense, Research Centre for Biology in Indonesian Institute of Science, Bogor, Indonesia.

2.2. Extraction. Leaves of $D$. pentandra were firstly sun dried for 3 days and were further dried in an oven at $40-45^{\circ} \mathrm{C}$ for $48 \mathrm{~h}$. The dried leaves were coarsely powdered using mechanical grinder. The powdered leaves extracted by water using reflux method for water extract and by ethanol $70 \%$ using maceration for ethanol extract. Ethanol extract was then fractionated using liquid-liquid extraction and resulted in ethanol fraction, ethyl acetate fraction, and n-hexane fraction. Each of the extracts and fractions were evaporated by vacuum evaporator.

2.3. Brine Shrimp Lethality Test (BSLT). The cytotoxic activity of extracts and fractions was performed using BSLT method described by McLaughlin et al. [19] with slight modification. Brine shrimps (Artemia salina Leach) larvae were used as test organisms. The cysts were placed and hatched for 48 hours with constant oxygen supply and under the light at room temperature. Twenty milligrams of the extract was added to the test tube containing $50 \mu \mathrm{L}$ Tween 80 in $10 \mathrm{~mL}$ of sea water to get stock solution $(2000 \mu \mathrm{g} / \mathrm{mL})$. The four graded sample concentrations $(1000,500,100$, and $10 \mu \mathrm{g} / \mathrm{mL})$ were used in the experiment. The experiments were done in triplicate. A test tube containing $50 \mu \mathrm{L}$ Tween 80 in $10 \mathrm{~mL}$ of sea water and 10 living brine shrimps was used as the negative control. The surviving larvae were counted after 24 hours of samples exposure. Larvae were considered dead if they did not exhibit any movement during 10 seconds of observation. Sample was considered toxic to brine shrimps if it had $\mathrm{LC}_{50}$ (lethal concentration 50\%) less than $1000 \mu \mathrm{g} / \mathrm{mL}$ [20]. The data of surviving brine shrimp was analyzed with SPSS 16.0 program for probit analysis to determine $\mathrm{LC}_{50}$ values and $95 \%$ confidence intervals.

2.4. Antiproliferative Activity Assay. Antiproliferative activity assay of extracts and fractions was conducted according to the method of Priosoeryanto et al. [21]. In vitro antiproliferative activity was assessed with K562 (human chronic myelogenous leukemia) and MCM-B2 (canine benign mixed mammary) cancer cell lines. The K562 and MCM-B2 cells were obtained from Laboratory of Tissue Culture, Department of Veterinary Clinic, Reproduction and Pathology, Faculty of Veterinary Medicine, Bogor Agricultural University, Indonesia. The cell lines were cultured in the tissue culture 24 -well plates at a density of $7 \times 10^{5}$ cells $/ \mathrm{mL}$. These cells were maintained in Dulbecco's Modified Eagle's Medium (DMEM), supplemented with $10 \%$ fetal calf serum, antibiotics (penicillin and streptomycin), and fungizone as antifungal. The extracts were dissolved in the tube containing $100 \mu \mathrm{L}$ of dimethyl sulfoxide (DMSO) in sterile distilled water. Each concentration of extract was added to the cultured well in triplicate. The tested concentrations of extract were 25, 50, 75, 100 , and $125 \mu \mathrm{g} / \mathrm{mL}$. DMEM was used as negative control and doxorubicin $(100 \mu \mathrm{g} / \mathrm{mL})$ was used as positive control. These cells were incubated in a humidified atmosphere of $5 \% \mathrm{CO}_{2}$ in air, at $37^{\circ} \mathrm{C}$. The cells were harvested when the cells growth in the negative control was confluent ( \pm 3 days). The cells were then stained using Trypan Blue Dye. The average of the total number of the cells on each well was counted under light microscope on 100x magnification using Improved Neubauer Haemocytometer.

2.5. Statistical Analysis. All analytical values shown represent the means of three replicates. Data of cell proliferation inhibition were analyzed using one-way ANOVA by SPSS 16.0 (Statistical Package for the Social Sciences) for Windows. Mean separation test between treatments was performed using Duncan's multiple range test. $P$ value $\leq 0.05$ was considered statistically significant.

\section{Results and Discussion}

In the drug development process, a large number of crude plant-derived extracts were firstly screened for their cytotoxic activity before they were further assayed using cancer cell lines or higher animals. Many researches showed that Brine Shrimp Lethality Test (BSLT) has a good correlation with various tumour cell lines. The cytotoxic activity of extract in BSLT is determined by $50 \%$ brine shrimps mortality response $\left(\mathrm{LC}_{50}\right)$. The plant extract was considered toxic to brine shrimps if it had $\mathrm{LC}_{50}<1000 \mu \mathrm{g} / \mathrm{mL}$ [20]. The toxicity level would show potency of extracts as anticancer.

In the present study, the $\mathrm{LC}_{50}$ values of $D$. pentandra leaves extracts and fractions have been shown in Table 1. Water extract, ethanol extract, and ethanol fraction of $D$. pentandra growing on clove had $\mathrm{LC}_{50}$ value greater than $1000 \mu \mathrm{g} / \mathrm{mL}$. The water extract showed no cytotoxic activity against brine shrimp. This result was in accordance with the water extracts of $D$. pentandra growing on Annona squamosa, Camellia sinensis, Spondias dulcis, and Stelechocarpus burahol $\left(\mathrm{LC}_{50}>1000 \mu \mathrm{g} / \mathrm{mL}\right)$ reported by Artanti et al. [1]. But this result was different from previous studies which reported that $D$. pentandra water extract from Kelantan, Malaysia, had cytotoxic activity against brine shrimps $\left(\mathrm{LC}_{50}\right.$ 
TABLE 1: Cytotoxic activity of $D$. pentandra leaves extracts and fractions against brine shrimps.

\begin{tabular}{|c|c|c|c|c|c|}
\hline \multirow{2}{*}{ Sample } & \multicolumn{4}{|c|}{$\%$ brine shrimp mortality (concentration in $\mu \mathrm{g} / \mathrm{mL}$ ) } & \multirow{2}{*}{$\mathrm{LC}_{50}(\mu \mathrm{g} / \mathrm{mL})$} \\
\hline & 10 & 100 & 500 & 1000 & \\
\hline Water extract & $16.67 \pm 0.58$ & $20.00 \pm 0.0$ & $26.67 \pm 0.58$ & $30.00 \pm 0.00$ & $>1000$ \\
\hline Ethanol extract & $0.00 \pm 0.00$ & $3.33 \pm 0.58$ & $3.33 \pm 0.58$ & $16.67 \pm 0.58$ & $>1000$ \\
\hline Ethanol fraction & $0.00 \pm 0.00$ & $3.33 \pm 0.58$ & $3.33 \pm 0.58$ & $10.00 \pm 0.00$ & $>1000$ \\
\hline Ethyl acetate fraction & $3.33 \pm 0.58$ & $23.33 \pm 1.15$ & $50.00 \pm 1.00$ & $70.00 \pm 1.73$ & 649.12 \\
\hline n-Hexane fraction & $40.00 \pm 0.00$ & $76.67 \pm 0.58$ & $100.00 \pm 0.00$ & $100.00 \pm 0.00$ & 55.32 \\
\hline
\end{tabular}

Note: percentages of brine shrimp mortality were expressed as mean \pm SD.

$251.22 \mu \mathrm{g} / \mathrm{mL}$ ) [4]. Since BSLT was used for preliminary screening for detection of anticancer compounds, this result showed that the use of $D$. pentandra decoction was less effective for cancer treatment. Nevertheless, water extract is still relatively safe to be consumed as antioxidant for cancer chemoprevention. Fitrilia et al. [11] reported that water extract of clove mistletoe had DPPH free radical scavenging activity with $\mathrm{IC}_{50}$ value of $11.4 \mu \mathrm{g} / \mathrm{mL}$. This high antioxidant activity was not significantly different with $\alpha$-tocopherol $\left(\mathrm{IC}_{50} 6.08 \mu \mathrm{g} / \mathrm{mL}\right.$ ). Previous research also reported that aqueous extract of $D$. pentandra had high antioxidant with $\mathrm{IC}_{50}$ value of $0.1 \%$ [22].

The clove mistletoe ethanol extract also showed no cytotoxic activity according to BSLT method (Table 1). But Daniel et al. [5] reported that ethanol extract of $D$. pentandra growing on soursop had cytotoxic activity with $\mathrm{LC}_{50}$ value of $4.53 \mu \mathrm{g} / \mathrm{mL}$. Nevertheless, the clove mistletoe ethanol extract had high antioxidant activity with $\mathrm{IC}_{50}$ value of $6.8 \mu \mathrm{g} / \mathrm{mL}$ [11]. Widowati et al. [23] reported that D. pentandra ethanol extract showed DPPH free radical scavenging activity $\left(\mathrm{IC}_{50}\right.$ $4.74 \mu \mathrm{g} / \mathrm{mL}$ ) and it was comparable with ascorbic acid and quercetin $\left(\mathrm{IC}_{50} 2.16\right.$ and $3.24 \mu \mathrm{g} / \mathrm{mL}$, resp.).

The data in Table 1 showed that ethanol fraction of $D$. pentandra had no cytotoxic activity against brine shrimps. This result was validated with previous research which showed that ethanol fraction of $D$. pentandra was nontoxic on male and female mice $\left(\mathrm{LD}_{50}>2000 \mathrm{mg} / \mathrm{Kg}\right.$ body weight $)$ [24], but methanol fraction of $D$. pentandra was toxic towards brine shrimp $[4,5]$.

The ethyl acetate and $\mathrm{n}$-hexane fractions of $D$. pentandra exhibited cytotoxic activity against brine shrimps (Table 1 ). The ethyl acetate and n-hexane fractions could kill 50\% of brine shrimps at concentration less than $1000 \mu \mathrm{g} / \mathrm{mL}$ (Table 1). It indicated that ethyl acetate and n-hexane fractions exhibit toxicity against brine shrimps. This result suggested that ethyl acetate and n-hexane fractions had potent anticancer activity in cancer cell lines. Nevertheless, n-hexane fraction was eleven times more potent than ethyl acetate fraction. Therefore, only $n$-hexane fraction was then considered to perform in antiproliferative activity assay in vitro.

The cytotoxic activity of ethyl acetate and n-hexane fractions of $D$. pentandra against brine shrimps was also reported by Daniel et al. [5]. The ethyl acetate fraction of $D$. pentandra on soursop as host plant had $\mathrm{LC}_{50}$ value of $2.13 \mu \mathrm{g} / \mathrm{mL}$, while $\mathrm{n}$-hexane fraction had $\mathrm{LC}_{50}$ value of $3305.04 \mu \mathrm{g} / \mathrm{mL}$. These results suggest that cytotoxic activity

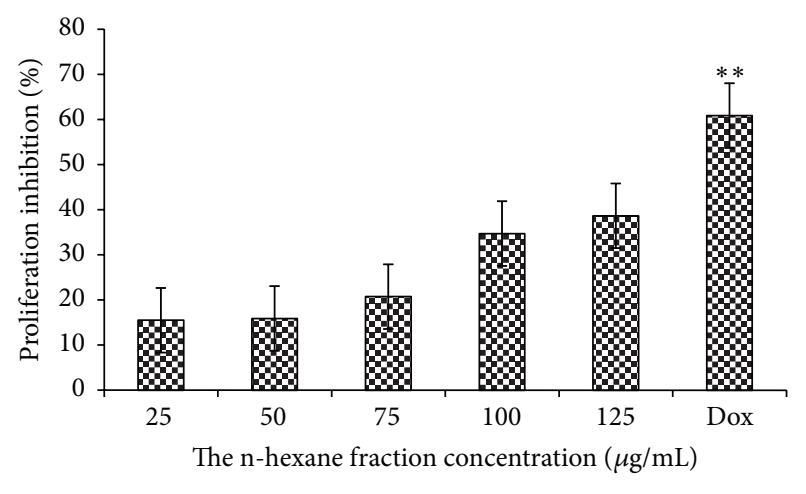

Figure 1: Percentage of proliferation inhibition K562 cells after treatment with $\mathrm{n}$-hexane fraction of clove mistletoe. The data is expressed as percentage of proliferation inhibition \pm SEM, as compared to the negative control $(100 \%)$. Level of significance is denoted as follows: ${ }^{* *} P<0.01$.

of mistletoe depends on its host plants and extraction solvent $[1,3]$.

Brine shrimps mortality after $\mathrm{n}$-hexane fraction exposure was expected to be associated with bioactive compound and not with starvation. This was confirmed by the absence of brine shrimps death in negative control group. Fitrilia et al. [11] reported that clove mistletoe leaves extract contained flavonoid and triterpenoids. Flavonoids and triterpenoids were toxic for brine shrimps in a concentration-dependent manner, so it might have contributed to brine shrimps mortality.

The $\mathrm{n}$-hexane fraction was reported to have the lowest antioxidant activity [11], but it exhibited the highest cytotoxic activity compared to other extracts and fractions that also contained flavonoid and triterpenoids. We assumed that the n-hexane fraction might contain other active compounds or other constituents might have had a synergistic effect on cytotoxic activity [24, 25].

The antiproliferative activity in vitro of $n$-hexane fraction was conducted with K562 (human chronic myelogenous leukemia) and MCM-B2 (canine benign mixed mammary) cancer cell lines. The K562 and MCM-B2 proliferation inhibitions after $\mathrm{n}$-hexane fraction treatment were presented in Figures 1 and 2. K562 and MCM-B2 cancer cells decreased with the increase of the given tested concentrations. At the lowest tested concentration $(25 \mu \mathrm{g} / \mathrm{mL}), \mathrm{n}$-hexane fraction could inhibit cell of both cancer cell lines. 


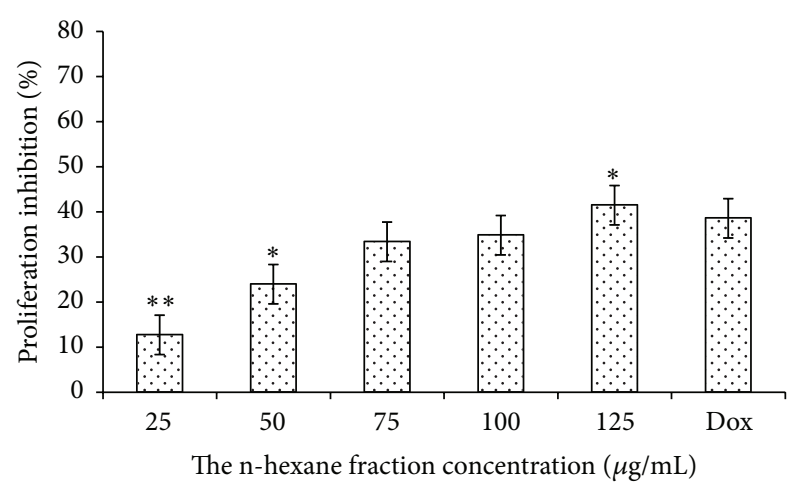

Figure 2: Percentage of proliferation inhibition MCM-B2 cells after treatment with $\mathrm{n}$-hexane fraction of clove mistletoe. The data is expressed as percentage of proliferation inhibition \pm SEM, as compared to the negative control $(100 \%)$. Level of significance is denoted as follows: ${ }^{*} P<0.05 ;{ }^{* *} P<0.01$.

The $\mathrm{n}$-hexane fraction could inhibit more than one-third of K562 and MCM-B2 cells at the tested concentration of $125 \mu \mathrm{g} / \mathrm{mL}$. Inhibition activity of $\mathrm{n}$-hexane fraction showed different effect on both cancer cell lines. Inhibition activity of $\mathrm{n}$-hexane fraction on MCM-B2 cells was slightly greater than K562 and commercial drug (doxorubicin). This is in accordance with Priosoeryanto et al. [26] who reported that anticancer activity from plants extracts depends on cancer cell lines that were used in experiment.

Previous study reported that ethanol extract of $D$. pentandra had very low antiproliferative activity in T47D cells with $\mathrm{IC}_{50}$ value of $728.05 \mu \mathrm{g} / \mathrm{mL}$ [27]. But $D$. pentandra aqueous extract could inhibit T47D cells proliferation with $\mathrm{IC}_{50}$ value of $1.2 \%$ and induce apoptosis [23]. Zainuddin and Sul'ain [28] also reported that $D$. pentandra ethyl acetate extract was effective towards MCF-7 breast cancer cell line with $\mathrm{IC}_{50}$ value of $14.42 \pm 0.34 \mu \mathrm{g} / \mathrm{mL}$, while methanol extract had $\mathrm{IC}_{50}$ value of $17.70 \pm 0.21 \mu \mathrm{g} / \mathrm{mL}$. D. pentandra leaves extract had no cytotoxic activity on mammalian normal cell lines (MDCK, L929, and Vero) [4, 28]. This suggests that $D$. pentandra had potency for cancer treatment and is relatively nontoxic and safe for traditional/complementary medicine.

The K562 cancer cell line is blast cell that was characterized by highly undifferentiated and difficult to mature functional cells [29]. Priosoeryanto et al. [30] reported that MCM-B2 might be derived from stem cells or atypical cells, so its cells were undifferentiated. Observation in vitro of MCMB2 cell line shows that these cells exhibit homogeneously morphological and immunohistochemical characteristics. MCM-B2 also shows less differentiation in cell culture. This undifferentiated character of K56 and MCM-B2 might contribute to inhibition of both cells growth when treated using $\mathrm{n}$-hexane fraction.

Treatment of K562 and MCM-B2 cells with n-hexane fraction of clove mistletoe resulted in different proliferation inhibition activity. It might be associated with membrane and nuclear receptors on K562 and MCM-B2 cells. Different receptors on K562 and MCM-B2 cells may have a different response for active compounds of clove mistletoe n-hexane fraction.

The $\mathrm{n}$-hexane fraction of clove mistletoe previously reported the presence of flavonoid and triterpenoid [11]. Flavonoid and triterpenoids are known to have important roles in cancer chemoprevention and chemotherapy [12]. These compounds were reported to have antioxidant activity, with capacity to scavenge reactive oxygen species (ROS) $[31,32]$. ROS have long been known to be cytotoxic and the cause of various diseases including cancer, diabetes, and neurodegenerative disease [33]. Anticancer mechanism of flavonoid and triterpenoids based on their antioxidant properties is associated with their ability to scavenge free radicals, inhibit the enzymes involved in ROS formation, and block the oxidation of cellular and extracellular compounds [32, 34]. Moreover, flavonoids contribute to modulating pathway of cancer proliferation, arresting the cell cycle, inducing apoptosis, and inhibiting angiogenesis $[31,35]$. Therefore, our present results provide better information on clove mistletoe traditionally used for cancer treatment.

\section{Conclusion}

Clove mistletoe leaves extract, particularly n-hexane fraction, exhibited cytotoxic activity with $\mathrm{LC}_{50}$ value of $55.31 \mu \mathrm{g} / \mathrm{mL}$. The $n$-hexane fraction also possessed antiproliferative activity on K562 and MCM-B2 cancer cell lines. The inhibition activity of clove mistletoe $\mathrm{n}$-hexane fraction at concentration $125 \mu \mathrm{g} / \mathrm{mL}$ on $\mathrm{K} 562$ and MCM-B2 was $38.69 \%$ and $41.5 \%$, respectively. Therefore, it was suggested that clove mistletoe had a potent natural anticancer activity.

\section{Competing Interests}

The authors declare that they have no competing interests regarding the publication of this paper.

\section{Acknowledgments}

The authors are thankful to the Indonesian Directorate General of Higher Education (DIKTI) for financial support and Faculty of Veterinary Medicine, Bogor Agricultural University, Indonesia, for providing cancer cell lines.

\section{References}

[1] N. Artanti, T. Firmansyah, and A. Darmawan, "Bioactivities evaluation of indonesian mistletoes (Dendrophthoe pentandra (L.) Miq.) leaves extracts," Journal of Applied Pharmaceutical Science, vol. 2, no. 1, pp. 24-27, 2012.

[2] A. O. Olaiya, M. O. Atayese, and I. O. Lawal, "Effect of spacing and intercropping on the rate infestation of parasitic weed on cocoa plantation," Nigerian Journal of Horticultural Science, vol. 17, pp. 88-192, 2012.

[3] Y.-J. Xiao, Y.-Z. Chen, B.-H. Chen, J.-H. Chen, Z.-X. Lin, and Y.L. Fan, "Study on cytotoxic activities on human leukemia cell line HL-60 by flavonoids extracts of Scurrula parasitica from four different host trees," Zhongguo Zhongyao Zazhi, vol. 33, no. 4, pp. 427-432, 2008. 
[4] N. A. S. N. Zainuddin and M. D. Sul'ain, "Phytochemical analysis, toxicity and cytotoxicity evaluation of Dendrophthoe pentandra leaves extracts," International Journal of Applied Biology and Pharmaceutical Technology, vol. 6, no. 1, pp. 108116, 2015.

[5] Daniel, C. Saleh, and M. S. L. Padin, "Bioactivity assay of soursop mistletoe leaves extracts (Dendrophthoe cf. pentandra [L.] Miq.) from East-Kalimantan," Mulawarman Scientific, vol. 11, no. 1, pp. 83-93, 2012.

[6] Gamal and E. Septananda, "Potential analysis of cottonwood parasite (Dendropthoe pentandra) stem extract in decreasing of mutant P53 protein expression on cervical cancer cell (HeLa Cells) in vitro," Jurnal Ilmiah Mahasiswa Kedokteran Indonesia, vol. 1, no. 2, pp. 11-15, 2013.

[7] I. Tristanti, Fatimawali, and W. Bodhi, "Uji efek hepatoprotektor ekstrak etanol daun benalu langsat (Dendrophthoe pentandra (L.) Miq.) terhadap kadar malondialdehid (MDA) pada hati tikus putih jantan galur wistar yang diinduksi karbon tetraklorida $\left(\mathrm{CCl}_{4}\right)$," Jurnal Ilmiah Farmasi, Indonesia, vol. 2, no. 3, pp. 75-78, 2013.

[8] M. H. Wicaksono and S. Permana, "Potensi fraksi etanol benalu mangga (Dendrophthoe pentandra) sebagai agen anti kanker kolon pada mencit (Mus musculus Balb/c) setelah induksi Dextran Sulvat (DSS) dan Azoxymethane (AOM)," Jurnal Biotropika, Indonesia, vol. 1, no. 2, pp. 75-79, 2013.

[9] H. Y. Ang, T. Subramani, S. K. Yeap et al., "Immunomodulatory effects of Potentilla indica and Dendrophthoe pentandra on mice splenocytes and thymocytes," Experimental and Therapeutic Medicine, vol. 7, no. 6, pp. 1733-1737, 2014.

[10] E. Suryanto and F. Wehantouw, "Free radical scavenging activities of phenolic extracts from clove parasite," Jurnal Bahan Alam Indonesia, vol. 6, no. 5, pp. 185-188, 2008.

[11] T. Fitrilia, M. Bintang, and M. Safithri, "Phytochemical screening and antioxidant activity of clove mistletoe leaf extract (Dendrophthoe pentandra (L.) Miq.)," IOSR Journal of Pharmacy, vol. 5, no. 8, pp. 13-18, 2015.

[12] W. Ren, Z. Qiao, H. Wang, L. Zhu, and L. Zhang, "Flavonoids: promising anticancer agents," Medicinal Research Reviews, vol. 23, no. 4, pp. 519-534, 2003.

[13] M. Jin, W. Zhao, Y. Zhang, M. Kobayashi, H. Duan, and D. Kong, "Antiproliferative effect of aaptamine on human chronic myeloid leukemia K562 cells," International Journal of Molecular Sciences, vol. 12, no. 11, pp. 7352-7359, 2011.

[14] M. Khanapur, R. K. Avadhanula, and O. H. Setty, "In vitro antioxidant, antiproliferative, and phytochemical study in different extracts of Nyctanthes arbortristis flowers," BioMed Research International, vol. 2014, Article ID 291271, 10 pages, 2014.

[15] J. Saengsai, S. Kongtunjanphuk, N. Yoswatthana, T. Kummalue, and W. Jiratchariyakul, "Antibacterial and antiproliferative activities of plumericin, an iridoid isolated from Momordica charantia vine," Evidence-Based Complementary and Alternative Medicine, vol. 2015, Article ID 823178, 10 pages, 2015.

[16] S. Tateyama, B. P. Priosoeryanto, R. Yamaguchi, K. Uchida, K. Ogiwara, and A. T. Suchiya, "In vitro growth inhibition activities of recombinant feline interferon on all lines derived from canine tumours," Research in Veterinary Science, vol. 59, no. 3, pp. 275-277, 1995.

[17] M. Watanabe, I. Y.-J. Chen, Y. Ishikura et al., "Tumor cell growth inhibition and cell differentiation analysis in a canine mammary tumor cell line (MCM-B2) treated with four chemical reagents,"
Journal of Veterinary Medical Science, vol. 71, no. 11, pp. 1413$1417,2009$.

[18] A. Soeksmanto, M. A. Subroto, H. Wijaya, and P. Simanjuntak, "Anticancer activity test for extracts of sarang semut plant (Myrmecodya pendens) to HeLa and MCM-B2 cells," Pakistan Journal of Biological Sciences, vol. 13, no. 3, pp. 148-151, 2010.

[19] J. L. McLaughlin, L. L. Rogers, and J. E. Anderson, “The use of biological assays to evaluate botanicals," Therapeutic Innovation \& Regulatory Science, vol. 32, no. 2, pp. 513-524, 1998.

[20] B. N. Meyer, N. R. Ferrigni, J. E. Putnam, L. B. Jacobsen, D. E. Nichols, and J. L. McLaughlin, "Brine shrimp: a convenient general bioassay for active plant constituents," Planta Medica, vol. 45 , no. 1, pp. 31-34, 1982.

[21] B. P. Priosoeryanto, S. Tateyama, R. Yamaguchi, and K. Uchida, "Establishment of a cell line (MCM-B2) from a benign mixed tumour of canine mammary gland," Research in Veterinary Science, vol. 58, no. 3, pp. 272-276, 1995.

[22] W. Widowati, T. Mozef, C. Risdian, H. Ratnawati, S. Tjahjani, and F. Sandra, "The comparison of antioxidative and proliferation inhibitor properties of Piper betle L., Catharanthus roseus [L] G.Don, Dendrophtoe petandra L., Curcuma mangga Val. extracts on T47D cancer cell line," International Research Journal of Biochemistry and Bioinformatics, vol. 1, no. 2, pp. 2228, 2011.

[23] W. Widowati, T. Mozef, C. Risdian, and Y. Yellianty, "Anticancer and free radical scavenging potency of Catharanthus roseus, Dendrophthoe petandra, Piper betle and Curcuma mangga extracts in breast cancer cell lines," Oxidants and Antioxidants in Medical Science, vol. 2, no. 2, pp. 137-142, 2013.

[24] C.-W. Tzeng, F.-L. Yen, L.-T. Lin et al., "Antihepatoma activity of Artocarpus communis is higher in fractions with high artocarpin content," Scientific World Journal, vol. 2014, Article ID 978525, 8 pages, 2014.

[25] R. Tundis, M. R. Loizzo, M. Bonesi, F. Menichini, G. A. Statti, and F. Menichini, "In vitro cytotoxic activity of Salsola oppositifolia Desf. (Ammaranthaceae) in a panel of tumour cell lines," Zeitschrift für Naturforschung C, vol. 63, pp. 347-354, 2008.

[26] B. P. Priosoeryanto, H. H. Gunanti, and R. Sumarny, "In vitro anti-proliferation and anti-invation activities of Mussaenda philippica chloroform and methanol extract on derived tumor cell lines," in Proceedings of the National Conference on Livestock Production and Veterinary Technology, pp. 782-788, Bogor, Indonesia, 2004.

[27] Katrin, A. A. Soemardji, A. G. Soeganda, and I. Soediro, "The acute toxicity of isolates from n-hexane and ethanolic fraction of Dendrophthoe pentandra (L.) Miq. which have immunostimulary activity," Majalah Farmasi Indonesia, vol. 16, no. 4, pp. 227-231, 2005.

[28] N. A. S. N. Zainuddin and M. D. Sul'ain, "Antiproliferative effect of Dendrophthoe pentandra extracts towards human breast adenocarcinoma cells (MCF-7)," Jurnal Teknologi, vol. 77, no. 2, pp. 35-39, 2015.

[29] H. P. Koeffler and D. W. Golde, "Human myeloid leukemia cell lines: a review," Blood, vol. 56, no. 3, pp. 344-350, 1980.

[30] B. P. Priosoeryanto, S. Tateyama, R. Yamaguchi, and K. Uchida, "Transplantation of a cell line derived from a canine benign mixed mammary tumour into nude mice," Journal of Comparative Pathology, vol. 113, no. 4, pp. 383-388, 1995.

[31] D. I. Hertzog and O. S. Tica, "Molecular mechanisms underlaying the anti-cancerous action of flavonoids," Current Health Sciences Journal, vol. 38, no. 4, pp. 145-149, 2012. 
[32] N. Han and M. Bakovic, "Biologically active triterpenoids and their cardioprotective and anti-inflammatory effects," Journal of Bioanalysis \& Biomedicine, vol. S12, article 005, pp. 1-11, 2015.

[33] G. Waris and H. Ahsan, "Reactive oxygen species: role in the development of cancer and various chronic conditions," Journal of Carcinogenesis, vol. 5, article 14, 2006.

[34] S. Kumar and A. K. Pandey, "Chemistry and biological activities of flavonoids: an overview," The Scientific World Journal, vol. 2013, Article ID 162750, 16 pages, 2013.

[35] P. Katyal, N. Bhardwaj, and R. Khajuria, "Flavonoids and their therapeutic potential as anticancer agents; biosynthesis, metabolism and regulation," World Journal of Pharmacy and Pharmaceutical Sciences, vol. 3, no. 6, pp. 2188-2216, 2014. 

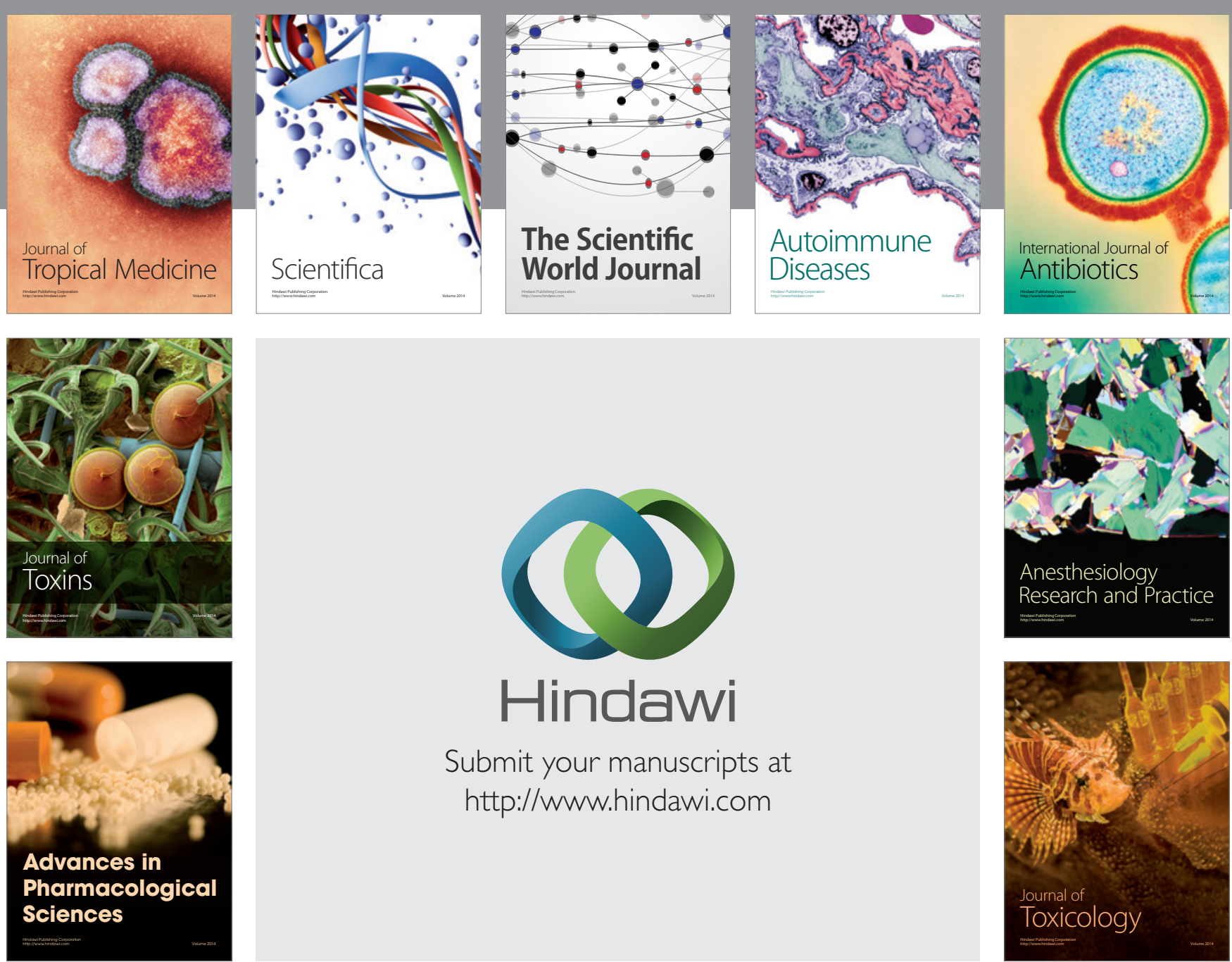

\section{Hindawi}

Submit your manuscripts at

http://www.hindawi.com
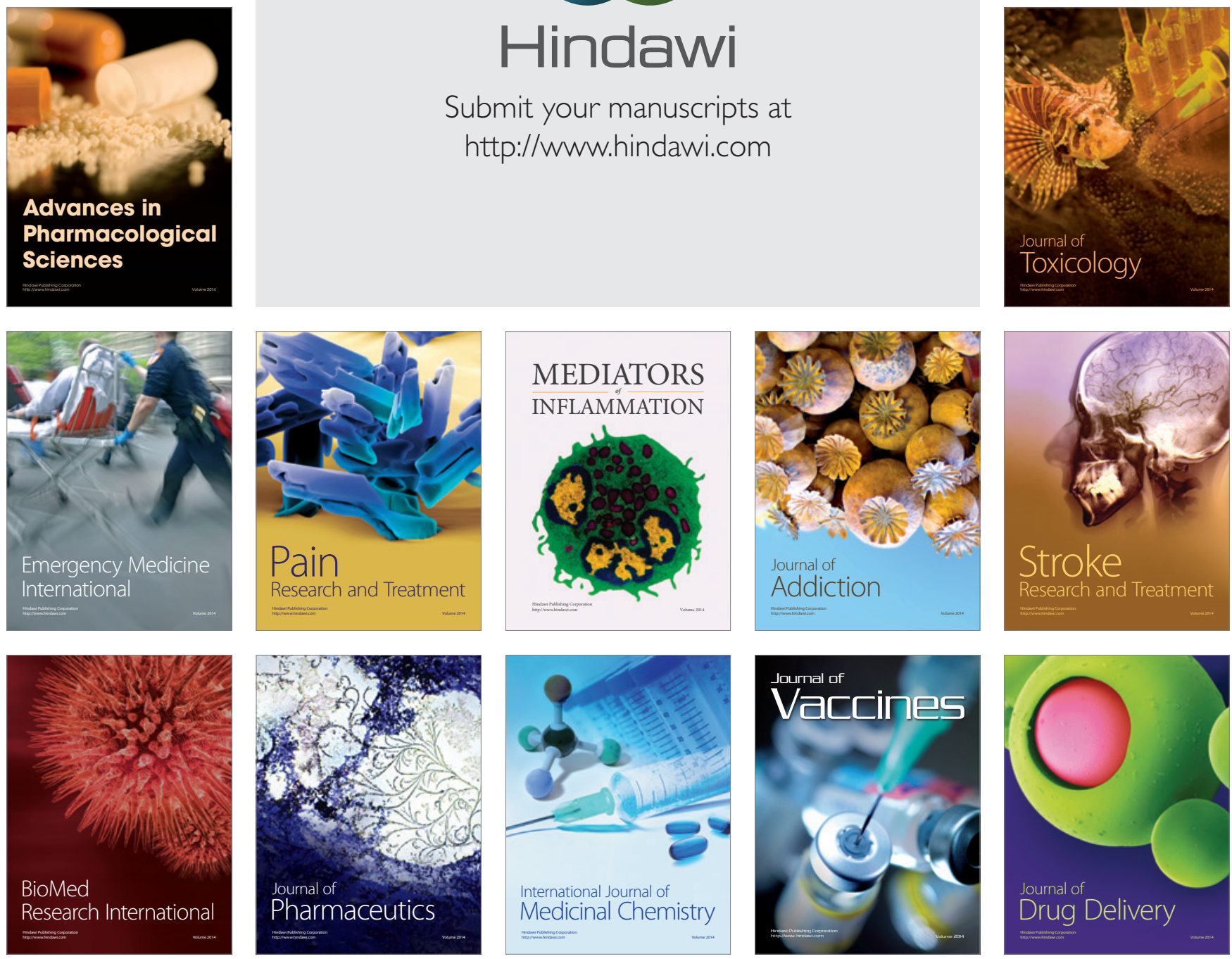